\title{
WIND AS A RESOURCE FOR SUMMER NAUTICAL RECREATION. GUINCHO BEACH STUDY CASE
}

\author{
WENZEL VERMEERSCH ${ }^{1}$ \\ MARIA JOÃO ALCOFORADO
}

\begin{abstract}
Guincho is known as the windiest beach of Portugal, ideal for nautical activities, such as windsurfing and kitesurfing. The main goals of this study are to explore the wind characteristics in Guincho and to compare the synoptic forecasts accessible to the public with actually occurring weather conditions. We used meteorological data, synoptical information, forecasts and field observations during the summers of 2009 and 2010. A sample of 124 days with good conditions for windsurfing were selected and classified into different groups. Within each group, the wind measured (and indirectly observed) in Guincho was compared to the results of the Global Forecast System (GFS). This analysis led to a useful classification allowing interpretation of GFS surface wind forecasts available to surfers at Guincho. We conclude that global weather models do not accurately forecast the wind, particularly due to model resolution and parameterisations, which do not detail local phenomena.
\end{abstract}

Keywords: Wind, Guincho, Portugal, summer, nautical sports, Global Forecast System.

Resumo - O VENTO COMO RECURSO PARA PRÁTICAS NÁUTICAS RECREATIVAS. O CASO DA PRAIA DO GUINCHO. A praia do Guincho, conhecida como a mais ventosa de Portugal, é ideal para a prática de windsurf e kitesurf. O principal objectivo deste estudo é explorar as características do vento no Guincho, comparando-as com as previsões meteorológicas, acessíveis ao público. Usaram-se dados meteorológicos, informações sinópticas, previsões e observações de terreno feitas nos verões de 2009 e 2010. Foi utilizada uma amostra de 124 dias, com boas condições para a prática de windsurf, a qual foi classificada em diferentes grupos. Dentro de cada grupo foi medida a intensidade do vento (também observada indirectamente), tendo sido depois comparados com os resultados do modelo americano de previsão (Global Forecast System - GFS). Esta análise conduziu a uma classificação, que é útil para interpretar as previsões do GFS acessíveis a quem pratica surf no Guincho. Chegou-se à conclusão de que os modelos de previsão não são suficientemente rigorosos para dar conta das condições de vento, porque a resolução e o tipo de parametrização dos modelos não atende às características particulares dos locais.

1 PhD Student, Researcher at CEG-IGOT-UL, Research Group CliMA - Climate and Environmental Changes. E-mail: wenzelwind@gmail.com

2 Former Full Professor at IGOT-UL, Researcher at CEG-IGOT-UL, Research Group CliMA. E-mail: mjalcoforado@campus.ul.pt 
Palavras-chave: Vento, Guincho, Portugal, Verão, desportos náuticos, Global Forecast System.

Résumé - LE VENT, UNE RESSOURCE POUR LES ACTIVITÉS NAUTIQUES RÉCRÉATIVES: LE CAS DE GUINCHO. La plage de Guincho, qui est connue pour être la plus ventée du Portugal, est un lieu idéal pour la pratique de la planche à voile et du kitesurf. L'objectif de cette étude est d'établir les caractéristiques du vent à Guincho et leur lien avec la situation synoptique. Elle est basée sur des données météorologiques (information synoptique, prévisions et observations sur le terrain), obtenues pendant les étés 2009 et 2010 . On a analysé un échantillon de 124 jours ayant des conditions adéquates pour la pratique de la planche à voile. Ils ont été analysés et classés par similarité en différents groupes. Pour chacun d'eux, la vitesse et la direction du vent ont été comparées aux données de prévision du modèle américain Global Forecast System (GFS), ce qui a permis d'établir une classification utile pour interpréter ladite prévision, facilement accessible aux pratiquants d'activités nautiques à Guincho. On en conclut que les modèles globaux de prévision sont insuffisamment précis et rigoureux, parce que leur résolution et leur paramétrisation ne détaillent pas assez les caractéristiques locales.

Mots clés: Vent, Guincho, Portugal, été, activités nautiques, Global Forecast System.

\section{INTRODUCTION}

For centuries, wind was a climatic resource for the transport of goods and people, allowing sailing boats to explore other territories and exchange products and merchandise. For instance, wind would be a key element for departure of the boats from the Tagus estuary from the $16^{\text {th }}$ century onwards (Alcoforado et al., 2000).

Nowadays, wind is hardly a maritime transport resource any more, replaced by the diesel motors powering modern cargo and aviation. But wind remains an essential climatic resource in the domain of nautical recreation. As Mathieson and Wall write: "Recreation embraces a wide variety of activities which are undertaken during leisure" (cited by Jennings, 2009:10). The article 24 of the 1948 Universal Declaration of Human Rights claims that "everyone has the right to rest and leisure, including reasonable limitation of working hours and periodic holidays with pay" (www.un.org/rights). The importance of the atmospheric conditions for sailors and more generally for people involved in any activity related with the sea is well-known. For those people, it is essential, and in some cases even vital, to possess knowledge of the wind conditions occurring during their maritime activity (Mayençon, 1982).

Guincho is a beach located a few kilometers from Cabo da Roca, the extreme western point of the European continent, and the western boundary of the $529 \mathrm{~m}$ Serra de Sintra. It consists of a large sand extension framed by low cliffs southwards towards Cabo Raso and high cliffs to the north, in the direction of Cabo da Roca (fig.1). 

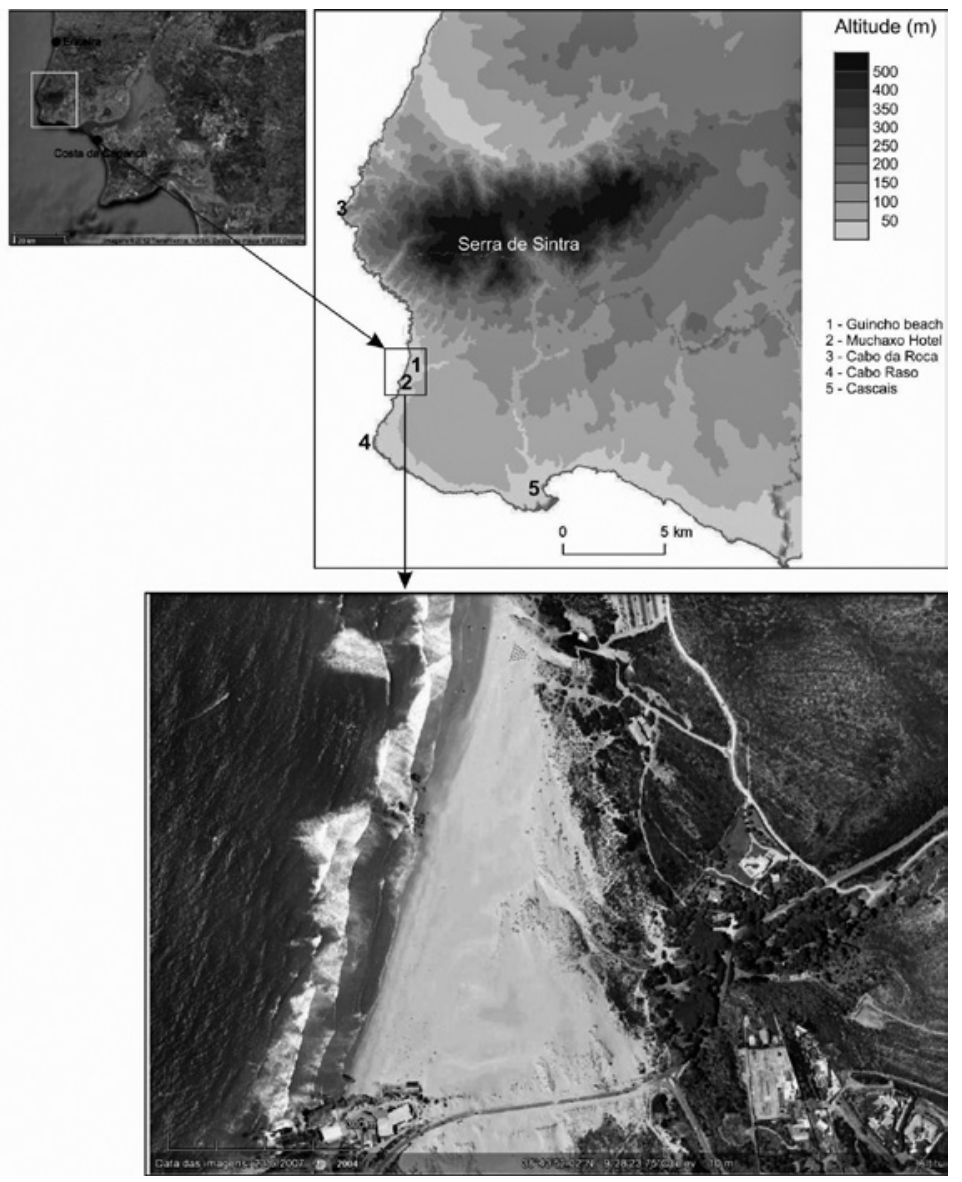

Fig. 1 - Location of the area under investigation. (See coloured version online) Fig. 1 - Localização da área estudada.

The most well-known and main climatic feature of this popular beach is the wind, acting as an almost tyrannical element (Alcoforado, 1984), which makes it often impossible for sunbathers to enjoy this paradise. Guincho is famous for being the windiest beach of Portugal, and is therefore also known as an ideal location for nautical activities.

Guincho's public visits the beach on an inconsistent basis and this is directly related to local weather. Some people come to the beach essentially for sun and sea bathing. The beach is under constant supervision due to strong waves and currents, and swimming in Guincho is often forbidden, which is usually signposted by a red flag. The dangerous waves are the reason why this is such a popular beach for extreme sports, attracting surfers on light wind days (less than 12 knotsi). With moderate wind conditions - between 12 and 20 knots - a new kind of visitor emerges. On these days, windsurfers generally occupy the northern part of the beach 
and kitesurfers the southern part. These sports need specific meteorological conditions, such as wind speeds above 15 knots and 12 knots, respectively. Table I shows the relation between wind speed and the type of visitor in Guincho.

Table I - Public attending Guincho beach according to wind speed.

Quadro I - Tipo de público presente na praia do Guincho de acordo com a velocidade do vento.

\begin{tabular}{c|l}
\hline $\begin{array}{c}\text { Wind speed classes } \\
\text { (knots) }\end{array}$ & Public attending \\
\hline$<12$ & $\begin{array}{l}\text { many bathers } \\
\text { many surfers and bodyboarders }\end{array}$ \\
\hline $12-16$ & $\begin{array}{l}\text { some bathers } \\
\text { some surfers and bodyboarders } \\
\text { some kitesurfers }\end{array}$ \\
\hline $16-20$ & $\begin{array}{l}\text { few bathers } \\
\text { few surfers and bodyboarders } \\
\text { many kitesurfers } \\
\text { some windsurfers }\end{array}$ \\
\hline$>20$ & $\begin{array}{l}\text { many kitesurfers } \\
\text { many windsurfers }\end{array}$ \\
\hline
\end{tabular}

Strong winds accompanied by violent waves make Guincho an ideal place for the practice of the above-mentioned sports, as well for holding surf, windsurfing and kitesurfing world championships. In fact, Guincho is recognised as one of the few beaches of the European Continent offering favourable weather conditions for windsurfing, kitesurfing and wave riding between April and September.

The research presented here draws on a wind study in Guincho between March and September 2009 and 2010, corresponding to the period of favourable wind conditions for windsurfing and kitesurfing, with winds blowing mostly from WNW, NW, NNW, N and NNE. However, wind forecasts used by the public rarely correspond to actual conditions on the beach. There are many cases of weak wind speed forecast, with observed wind speeds of 20 knots, or forecast of 15 knots and actual wind speed of over 35 knots.

This essay is a work of geography, and more specifically, applied climatology. At this stage, it will be limited to the analysis of surface wind modifications observed in the study area, without considering the vertical structure of the atmospheric boundary layer.

The study has two goals: first, it is an attempt to understand the behaviour of the wind in Guincho; and second, it tries to compare the forecasts accessible to the public with actually occurring weather conditions. In the next section, the study area will be presented, as well as the different general wind patterns affecting Portugal during summer time. In section III, a classification of 124 summer days based on synoptic forecast and a comparison with the actual wind conditions onshore and offshore are described. Section IV shows the results of this classification and section V the interpretation of the wind forecasts for nautical sports. Finally, in section VI, the results are discussed and the conclusion is presented. 


\section{STUDY AREA}

A good geographical understanding of the area is essential to carry out a wind study (Bernot, 2005), as well as to establish a relationship between the spatial modification of wind patterns and the physical elements of the study area.

\section{Location and topography}

The Serra de Sintra is the main relief of the coastal platform, peaking 529 meters above sea level (fig.1). The mountain, located northwards of the beach, has an elliptical shape, its longest axis $(\sim 10 \mathrm{~km})$ running from west to east and the shorter one $(\sim 5 \mathrm{~km})$ from north to south. There is a valley that partly divides the east-west peak line of the massif. To the west, the mountain features regular abrupt slopes, ending with a number of high cliffs at Cabo da Roca (fig.1).

The altitude of Cascais' platform, located southwards of Serra de Sintra does not exceed 150 meters. Both the west and the south shores are relatively flat.

\section{Summer wind patterns}

Wind patterns in the region of Cascais are complex and the regional and local wind effects are varied. N and NW winds are dominant all throughout the year, as revealed by the area's weather stations (Alcoforado, 1984; Alcoforado et al., 2006). At Cabo da Roca's weather station (fig. 2), NW winds are frequent all over the year, but $\mathrm{N}$ winds occur more often during the summer period. $\mathrm{N}$ and $\mathrm{NW}$ wind frequency reaches almost $80 \%$ in July and August and between 40 and 65\% in April, May, June, September and October.

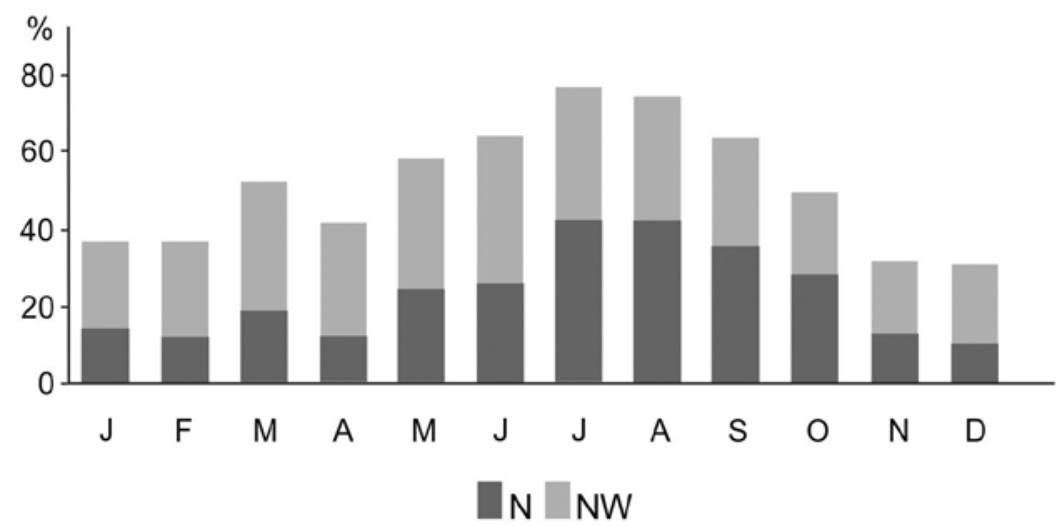

Fig. 2 - Percentage of N and NW winds at Cabo da Roca (1931-1960)

Fig. 2 - Percentagem de ventos de N e NW no Cabo da Roca (1931-1960).

Data from the Serviço Meteorológico Nacional 1965, in Neves, 2004 
The regional $\mathrm{N}$ and NNW winds blow moderately over Portugal's western shore, between the Azores high and the low over the Iberian Peninsula (fig. 3, Alcoforado et al., 2006). A high horizontal pressure gradient generates high wind speeds, increased at the end of the afternoon partly due to thermal effects; minimal wind speeds are observed at sunset (Instituto Hidrográfico, 2004). If the pressure gradient is weaker, the wind on the western shore of Portugal usually blows from the $\mathrm{W}$ or NW, but also with maximum speeds at the end of the afternoon. At night, the breeze blows offshore from $\mathrm{E}$ or SE. These changes in direction occur essentially if the daily thermal amplitude is high and if the sky is clear (Instituto Hidrográfico, 2004), but Guincho appears as a particular case.

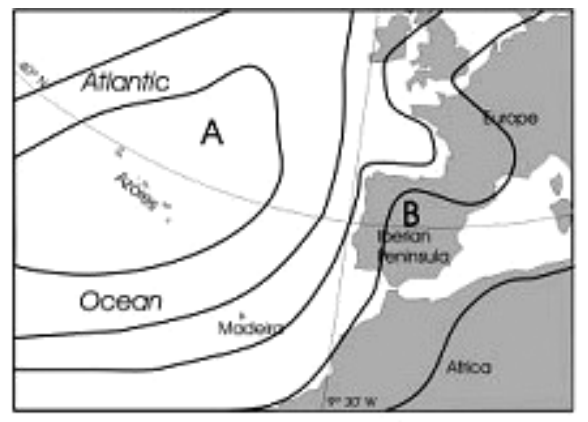

Fig. 3 - Synoptic situation of a typical summer day.

Fig. 3 - Situação sinóptica de um dia típico de Verão. Source: Alcoforado et al., 2006

In regard to the regional effects, the Serra de Sintra plays a major role in wind speed and direction changes (Alcoforado, 1984). The speed may slow down or, in contrast, accelerate the regional north wind, depending on air stability and on the trajectory of the air mass (Simpson, 1994; Bernot, 2005). Although hardly any wind data are available for Guincho, this site has most certainly more NW and NE winds than Cabo da Roca, shown by the wind-shaped trees (Alcoforado, 1984). In Guincho, the NW wind circumvents the Serra de Sintra's obstacle, and NE winds are channeled towards Guincho by the valleys on the southern slope of Serra de Sintra.

The local effects are mostly related to topographical features and the sandy soil cover, as a beach on the lee side of the mountain, continued by longitudinal dunes, represents a large area acting as a heat reservoir; by light to moderate offshore geostrophic winds (typically less than $12 \mathrm{kt}$ ), the onset of the sea breeze is favoured (Watts, 1973; Simpson, 1994; Bernot, 2005).

In meteorology, wind is named after the direction it blows from. North wind means wind blowing from the north. As shown in fig. 4, for surfers, onshore winds mean winds blowing towards the coast (independently of its direction). Offshore winds are those that blow away from the shore and sideshore those that blow parallel to the coastline. 


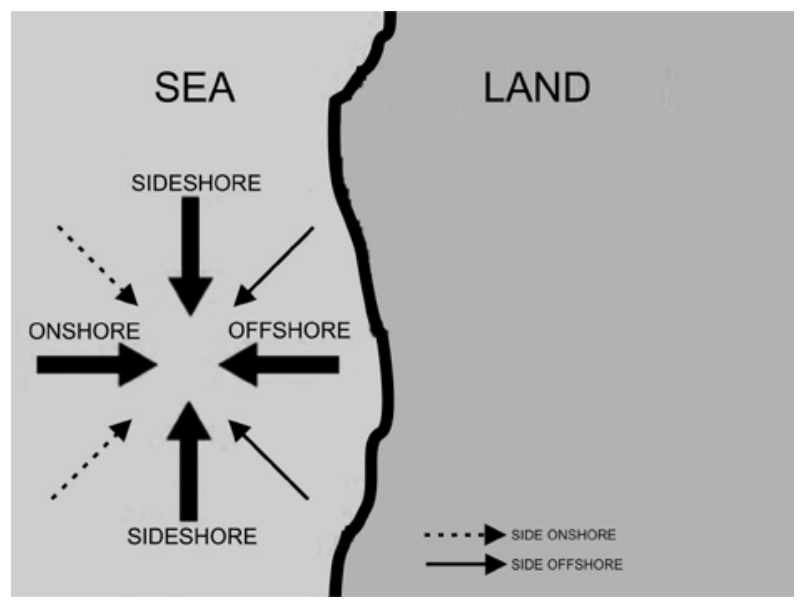

Fig. 4 - Wind direction names in relation to the shoreline. (See coloured version online)

Fig. 4 - As denominações da direcção dos ventos em função do litoral.

\section{DATA AND SELECTION CRITERIA}

This analysis is based on 124 days, selected among two spring and summer periods between March 2009 and October 2010, during which meteorological and synoptical data were used, as well as forecast models and personal field observations.

\section{Data}

\subsection{Meteorological data}

The following meteorological data were used:

- Hourly wind and temperature data for the spring and summer periods 2009-2010 from Cabo Raso, a weather station of the Portuguese weather services (currently called Instituto Português do Mar e da Atmosfera, IPMA) located just under $4 \mathrm{~km}$ southwards of Guincho (figs. 1 and 5a): average wind speed and wind gusts, as well as mean wind direction.

- Hourly wind data during the spring and summer of 2010 (figs. 1 and 5b), from an anemometer above Muchaxo hotel. This private meteorological station is located at the southern end of Guincho beach. The anemometer is located almost $20 \mathrm{~m}$ above the beach and may indicate different wind speed and direction than on the beach or over the sea. Data are issued from a wireless Oregon Scientific Weather station (model WMR88) using a mechanic vane and are directly monitored on the internet. In some instances, the weather station indicated 15-22 knot winds, while on the beach there was no wind. This was observed on 15 May 2010 by the first author. 

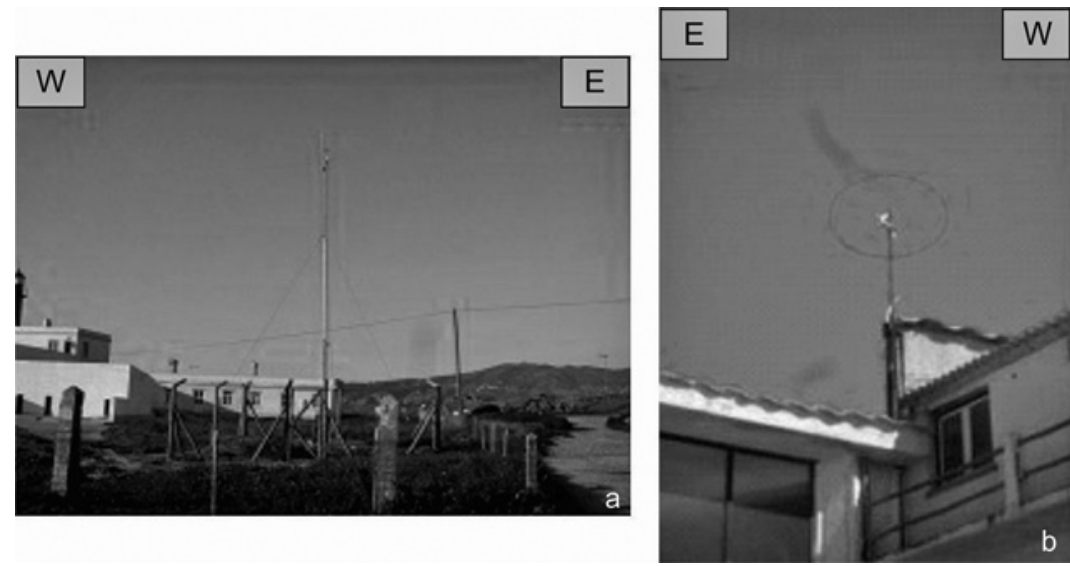

Fig. 5 - Weather stations at Cabo Raso (a) and on the southern part of Guincho Beach, above Muchaxo Hotel (b).

Fig. 5 - Estações meteorológicas do Cabo Raso (a) e do limite sul da praia do Guicho, junto ao Hotel Muchaxo (b).

\subsection{Synoptical situation and forecasts}

The subsequent sources were used:

- Synoptic situations, based on the analysis of maps issued by the German Weather Services (Deutsche Wetterdienst), representing Europe and the Northeast Atlantic Ocean and available for $0,6,12$ and $18 \mathrm{~h}$, for the interpretation of the synoptic situations favouring wind in Guincho and its daily evolution.

- Forecast data based on a global weather forecast, Global Forecast System (GFS), issued by the National Center for Environmental Prediction (NCEP); the forecasts refer to the subsequent 192 hours, with a resolution of $27 \mathrm{~km}$. GFS models consider only global thermal and wind effects according to the resolution. Thus, GFS does not detail local wind effects. This forecast data is the most common information relied on by sports practitioners.

- In order to have a better perception of the local phenomena, the analysis also used Predictwind, a forecast model with $1 \mathrm{~km}$ resolution, created by the Commonwealth Scientific and Industrial Research Organisation (SCIRO) and made available on Predictwind web site by Jon Bilger, "Alinghi's" weather team manager, during the America's Cup 2003-2010.

\subsection{Field Observations}

To further explore local phenomena, fieldwork has been essential. Different types of observations were carried out:

- Personal observations of wind (presence/absence; high/low speed) and measurement of wind speed. In addition to the wind measurements at Muchaxo (2, on fig. 1), daily personal field observations were carried out. In fact, there are great local wind changes, which can be analysed by field (or sea) observations, e.g. cases when there is 
no wind in the wave section, but Muchaxo weather station indicates wind speeds of 15-25 knots. These phenomena were observed visually, using the Beaufort scale, and through actual practice of nautical activities such as windsurfing. Furthermore, a portable anemometer was used for the verification of conditions on several locations at the beach, such as its northern and southern parts, both on the sand and on the cliffs.

- Observation of clouds in the study area and in relation to the main relief. Some are well defined: (i) A local cloud band located north of the Serra de Sintra, which extends over the sea (fig. 6a); (ii) A local cloud band above the Serra de Sintra; from the Guincho beach, it seems that the clouds are blocked, but in reality, the clouds disappear once they pass over the relief (fig. 6b); (iii) The clouds above the relief do not always form a straight line, as in figure $6 a$ and $6 \mathrm{~b}$, but can be characterised by a few cumulus clouds on top of the Serra de Sintra (6c) or on top and southwards (6d); (iv) a cloudy sky above the whole Serra the Sintra, and with some precipitation (fig. 6e).

- Indicators used in water sports, in particular windsurfing (e.g. sail and board sizes). The size of the gear used for the practice of windsurfing is chosen after taking into consideration the wind speed. A professional windsurfer from Ericeira, who measures the wind speed before windsurfing, in order to choose the adequate sail and board, made his personal statistics available to us. Table II shows the different sizes of sail used according to the wind speed.

Table II - Wind speed versus sail size in Ericeira.

Quadro II - Velocidade do vento versus tipo de prancha na Ericeira.

\begin{tabular}{cc}
\hline Average wind speed (knots) & Sail size used $\left(\mathrm{m}^{2}\right)$ \\
\hline $10-14$ & 6.7 \\
$15-20$ & 5.9 \\
$18-25$ & 5.3 \\
$22-27$ & 4.7 \\
$26-30+$ & 4.1 \\
\hline
\end{tabular}

Source: Henrique Fonseca, personal information.

\section{Studied days selection criteria}

From the available period, a sample of days was selected in which there were favourable windsurf conditions. Analysis of the selected days showed that the minimum conditions required for the practice of windsurfing are a wind speed of at least 15 knots and a wind direction NW to NNE.

This data was firstly grouped according to the surface synoptic wind depicted by GFS model, separating days with moderate to strong wind speed forecast $(>12$ knots, Group A) from days with a weak wind speed forecast $(<12$ knots, Group B). Furthermore, days were categorised by similarity of observed weather conditions on the Guincho beach, such as the evolution of wind speed and direction throughout the day, as well as cloud phenomena. 


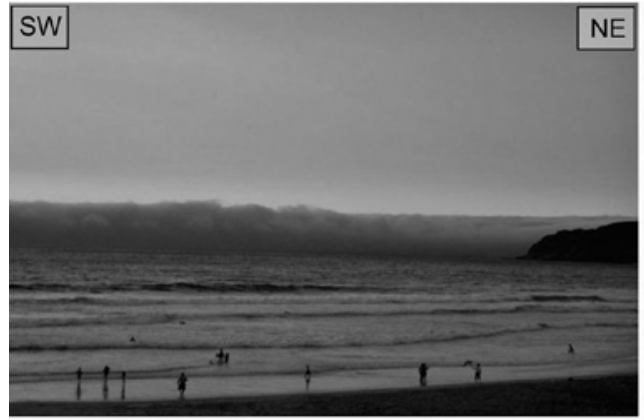

a - Cloud band over the sea

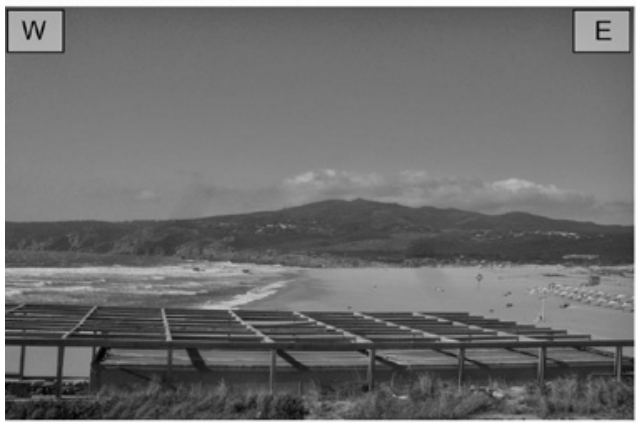

c - Some cumulus above the relief

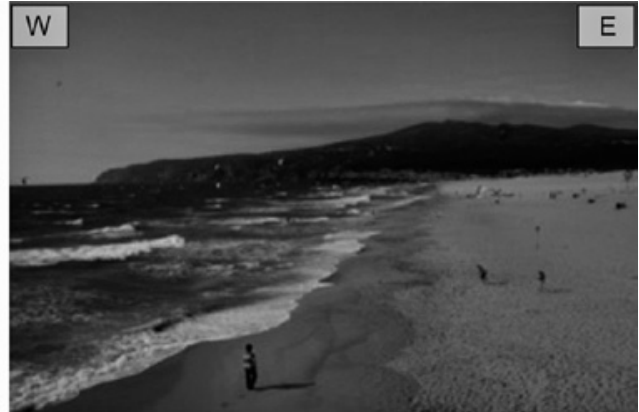

b - Cloud band over the relief

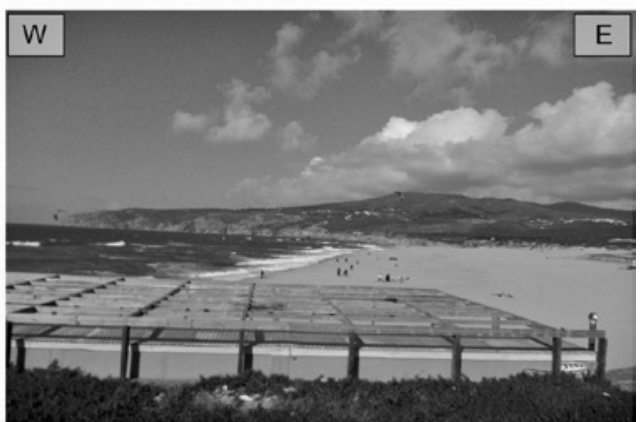

$\mathrm{d}$ - Cumulus on top and southwards of the relief

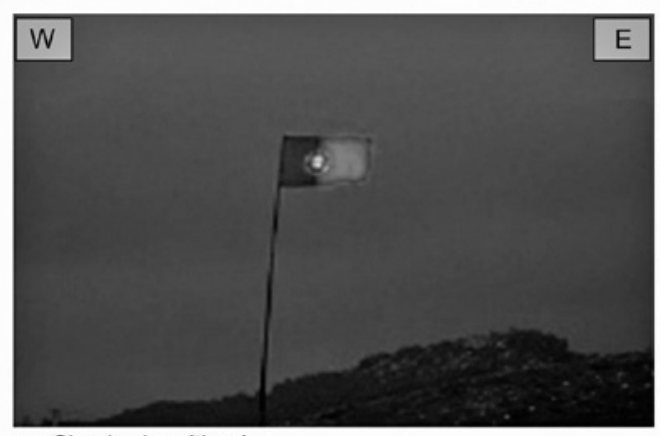

e - Cloudy sky with rain

Fig. 6 - Typical nebulosity features on the southern slope of Serra de Sintra and over the sea.

(See coloured version online)

Fig. 6-Aspectos típicos de nebulosidade na vertente Sul da Serra de Sintra e sobre o mar.

A description of the typical synoptic situation will be next presented for each group, as well as an analysis of temperature data of Cabo Raso, and wind observations in Ericeira, located about $25 \mathrm{~km}$ north, on the windward side of the Serra de Sintra (Vermeersch, 2011). 


\section{RESULTS}

Tables III and IV show the main characteristics of the two large wind groups: group A (strong wind forecast) and B (weak wind forecast). Each group is subdivided in several smaller categories, as referred before.

\section{Group A description}

For groups A1 and A2, the GFS forecast predicts a moderate (12-20 knots) NNW or $\mathrm{N}$ wind. The synoptic situation is characterised by a strong pressure gradient between a high pressure over the Atlantic Ocean and a thermal low over the Iberian Peninsula (fig. 3). In some cases, the synoptic pressure maps show the presence of a cold front initiated in the anticyclone's border. In these specific cases, the Nortada (very frequent north winds, especially in the summer months) is considerably accelerated in Guincho, with average wind speeds of around 20-35 knots. The main difference between the two groups is that the wind blows continuously during the afternoon for group A1 and during the whole day for group A2. The wind is characterised by strong gusts, reaching 50 knots. Wind on top of the boundary layer is brought down to the ground by turbulence. Gusts are due to vertical instability (Miranda, 2001). These cases occur frequently during the summer period (June, July and August), often spanning several days, e.g. 7-9 July 2009 and 5-9 August 2009.

For group A3, although the GFS forecast is similar to groups A1 and A2 (NNW and N, 12-20 knots), wind regimes are completely different throughout the day. The synoptic situation is similar to group A1 and A2, although the anticyclone's center is located north of the Iberian Peninsula by the end of the day.

The wind blows onshore (from the sea), in a very irregular way, between 5 and 25 knots. Nevertheless, at the end of the day (17-18h), wind speed increases suddenly, veering to NNW or N, and showing similar conditions at the end of the day as in groups A1 and A2.

Group A4 is characterised by a higher GFS wind speed forecast than the former groups A1, A2 and A3, predicting a strong NNW and N wind (12-28 knots). Gradient wind is not linked to a thermal low over the Iberian Peninsula, but is due to a low located over the Western Mediterranean, generating a strong wind across the whole Portuguese western shore. Wind in Guincho is very irregular during the whole day: Strong winds, characterised by very strong gusts ( 45 knots), interrupted by periods of calm. This irregular wind is due to the emergence of wind eddies on the leeward of the mountain. In cases of wind eddies on the slopes of the mountain, wind can be variable, blowing hard for a moment, before calming down shortly afterwards. These cases occur more often during the spring and are characterised by either a clear sky or the presence of some cumulus.

In groups A5 and A6, when GFS forecasts predict a moderate NW or NNW wind (8-20 knots), the wind is not blowing faster in the Guincho area. A5 appears to be the only group where the wind forecasts correspond to the actual observed wind in Guincho, representing only 5\% of the analysed days. These are cloudy days, with rainfall and onshore wind. They occur in spring or autumn. 
Group A6 does not correspond to strong winds, although moderate winds are forecasted. In fact, wind in Guincho is very irregular and gusts do not exceed 20 knots. In the wave section, on the shore, the wind is light. There are clouds around the Serra de Sintra, but in Lisbon the sky is clear. In Costa da Caparica (fig. 1), the wind is stronger than in Guincho and less irregular.

Table III - Some characteristics of the wind groups with a moderate or strong

GFS wind forecast (Group A).

Quadro III - Algumas características dos grupos de ventos, classificados pelo GFS como moderados a fortes (Grupo A)

\begin{tabular}{|c|c|c|c|c|c|c|}
\hline Group & $\begin{array}{l}\text { OBSERVED wind in } \\
\text { Guincho (direction } \\
\text { and speed) }\end{array}$ & $\begin{array}{l}\text { PREDICTED } \\
\text { wind for Guincho, } \\
\text { GFS forecast } \\
\text { (Direction and wind } \\
\text { speed) }\end{array}$ & Synoptic situation & $\begin{array}{l}\text { Temperatures } \\
\text { at Cabo Raso }\end{array}$ & Cloud incidence & $\begin{array}{l}\text { OBSERVED } \\
\text { wind at Ericeira }\end{array}$ \\
\hline A1 & $\begin{array}{l}\text { - Strong NNW wind } \\
\text { starting in the } \\
\text { afternoon } \\
\text { - 20-30 knots, gusts } \\
\text { reaching } 45 \text { knots }\end{array}$ & $\begin{array}{l}\text { - Afternoon: NNW } \\
\text { and N 12-20 knots } \\
\text { or (on other days): } \\
\text { - NNW and N } 12 \text { to } \\
20 \text { knots the whole } \\
\text { day }\end{array}$ & $\begin{array}{l}\text { - Anticyclone located } \\
\text { westwards of Portugal } \\
\text { - Iberian thermal low } \\
\text {-Atmospheric pressure } \\
\text { of } 1015-1020 \mathrm{hPa} \text { over } \\
\text { western Portugal }\end{array}$ & $\begin{array}{l}\text { - Low thermal daily } \\
\text { amplitude } \\
\left.\text { (circa } 2^{\circ} \mathrm{C}\right) \\
\text { - Maximum } \\
\text { temperature below } \\
20^{\circ} \mathrm{C}\end{array}$ & $\begin{array}{l}\text { - Cloud band over } \\
\text { Serra de Sintra } \\
\text { (fig. 6b) } \\
\text { - Stratus away from } \\
\text { the Serra. }\end{array}$ & - Around 15 knots \\
\hline A2 & $\begin{array}{l}\text { - Strong NNW wind } \\
\text { the whole day } \\
-20-30 \text { knots, gusts } \\
\text { reaching } 50 \text { knots }\end{array}$ & $\begin{array}{l}-\mathrm{NNW} \text { and } \mathrm{N} \\
-10-20 \text { knots the } \\
\text { whole day }\end{array}$ & $\begin{array}{l}\text { - Anticyclone located } \\
\text { westwards of Portugal } \\
\text {-Iberian thermal low } \\
\text {-Atmospheric pressure } \\
\text { of } 1015-1020 \mathrm{hPa} \text { over } \\
\text { western Portugal }\end{array}$ & $\begin{array}{l}\text { - Low thermal daily } \\
\text { amplitude } \\
\text { (circa } 2^{\circ} \mathrm{C} \text { ) } \\
\text { - Maximum } \\
\text { temperature below } \\
20^{\circ} \mathrm{C}\end{array}$ & $\begin{array}{l}\text { - Cloud band over } \\
\text { Serra de Sintra; } \\
\text { or } \\
\text { - Cumulus over Serra } \\
\text { de Sintra. (fig. 6c) }\end{array}$ & - Around 15 knots \\
\hline A3 & $\begin{array}{l}\text { - Variable wind } \\
10-30 \text { knots NW on } \\
\text { the beach, stronger } \\
\text { NW wind offshore } \\
\text { - By the end of the } \\
\text { day, strong NNW } \\
\text { or N wind, } \\
20-30 \text { knots, gusts } \\
\text { reaching } 45 \text { knots }\end{array}$ & $\begin{array}{l}-\mathrm{N} \\
-12-20 \text { knots }\end{array}$ & $\begin{array}{l}\text { - Anticyclone } \\
\text { northwards of the } \\
\text { Peninsula. } \\
\text { - Iberian thermal low } \\
\text { - Atmospheric pressure } \\
\text { between } 1020-1025 \mathrm{hPa} \\
\text { over western Portugal }\end{array}$ & $\begin{array}{l}\text { - Relatively low } \\
\text { thermal daily } \\
\text { amplitude }\left(3-4^{\circ} \mathrm{C}\right) \\
\text { - Maximum } \\
\text { temperature below } \\
20^{\circ} \mathrm{C}\end{array}$ & $\begin{array}{l}\text { - Stationary cloud } \\
\text { over the beach } \\
\text { - At night, clouds } \\
\text { over Serra de Sintra } \\
\text { (fig.6a.) }\end{array}$ & $\begin{array}{l}-20-25 \text { knots } \\
\text { during the } \\
\text { afternoon }\end{array}$ \\
\hline A4 & $\begin{array}{l}\text { - Very irregular NNW } \\
\text { wind, 10-35 knots, } \\
\text { with violent gusts, } \\
\text { followed by calm } \\
\text { moments }\end{array}$ & $\begin{array}{l}\text { - Morning: } \mathrm{N} \text { and } \\
\text { NNE12-28 knots, } \\
\text { - Afternoon: NNW, } \\
\text { with higher speeds } \\
\text { in the afternoon and } \\
\text { in the evening }\end{array}$ & $\begin{array}{l}\text { - Anticyclone over the } \\
\text { Atlantic } \\
\text { - Low pressure } \\
\text { (not thermal) over } \\
\text { western Mediterranean }\end{array}$ & $\begin{array}{l}\text { - Low thermal daily } \\
\text { amplitude } \\
\text { (circa } 2^{\circ} \mathrm{C} \text { ). } \\
\text { - Maximum } \\
\text { temperature below } \\
17^{\circ} \mathrm{C}\end{array}$ & $\begin{array}{l}\text { - Some cumulus away } \\
\text { from the Serra } \\
\text { (fig } 6 \mathrm{~d} \text {.) } \\
\text { or } \\
\text { - Clear sky }\end{array}$ & $-20-25$ knots \\
\hline $\begin{array}{l}\text { A5 } \\
\text { Wind } \\
\text { similar to } \\
\text { GFS } \\
\text { forecasts }\end{array}$ & $\begin{array}{l}\text { - WNW-NW wind, } \\
\text {-10-15 knots, with } \\
\text { gusts reaching } \\
20-25 \text { knots }\end{array}$ & $\begin{array}{l}-\mathrm{NW} \text { and NNW } \\
-8 \text { to } 20 \text { knots }\end{array}$ & $\begin{array}{l}\text { - Anticyclone over the } \\
\text { Atlantic } \\
\text { - Low pressure } \\
\text { (not thermal) over } \\
\text { western Mediterranean }\end{array}$ & $\begin{array}{l}\text { - Low to moderate } \\
\text { thermal amplitude } \\
\text { (circa } 4^{\circ} \mathrm{C} \text { ) } \\
\text { - Maximum } \\
\text { temperature below } \\
18^{\circ} \mathrm{C}\end{array}$ & $\begin{array}{l}\text { - Cumulus passing } \\
\text { over the Serra } \\
\text { - Precipitation. } \\
\text { (fig. 6e) }\end{array}$ & - Weak/ onshore \\
\hline A6 & $\begin{array}{l}\text { - NW-NNW } \\
\text { - very irregular wind } \\
\text { - 0-20 knots, } \\
\text { - "no wind bubble" }\end{array}$ & $\begin{array}{l}-\mathrm{NW} \text { and NNW } \\
-10 \text { to } 20 \mathrm{knots}\end{array}$ & $\begin{array}{l}\text { - Anticyclone over the } \\
\text { Atlantic } \\
\text { - Low pressure } \\
\text { (not thermal) over } \\
\text { western Mediterranean }\end{array}$ & $\begin{array}{l}\text { - Low thermal } \\
\text { amplitude } \\
\text { (circa } 2^{\circ} \mathrm{C} \text { ). } \\
\text { - Maximum } \\
\text { temperature below } \\
20^{\circ} \mathrm{C}\end{array}$ & $\begin{array}{l}\text { Cloudy on the Serra } \\
\text { and on leeside (fig 6d) } \\
\text { Clear sky over } \\
\text { Caparica }\end{array}$ & - Weak and onshore \\
\hline
\end{tabular}




\section{Group B description}

A weak GFS wind forecast was given for a considerable number of other days (group B1, B2, B3, B1+3 and B4), lower than 10-12 knots, but in every group, in Guincho, wind actually blows between 15 and 25 knots at certain times of day. Synoptic situation for these groups is variable, although there is one common characteristic: the study area is located in a low gradient pressure area.

For group B1, wind blows moderately in Guincho from the NW, between 12-13h and 15-16h, at wind speeds between 15 and 25 knots. After 16h, wind drops on the beach and in the wave section, and blows strong only over the sea, $50-150 \mathrm{~m}$ from the beach. Group B2 occurs with a weak GFS wind forecast, lower than 5 knots. In Guincho, wind blows from the NW (15 to 20 knots) between $14 \mathrm{~h}$ and $17 \mathrm{~h}$.

The cases outlined in group B3 present a low GFS wind forecast: weak NE or $\mathrm{E}$ wind during the morning and blowing from $\mathrm{NNW}$ or $\mathrm{N}$ in the afternoon, with wind speeds of 8-10 knots. In actual fact, in Guincho, wind blows weak offshore in the morning, and from NW quite weak in the afternoon, before veering to the $\mathrm{N}$ or NNE and considerably increasing its speed to reach 20-25 knots at the end of the day. Daily thermal amplitude may be important, due to an increase of temperature at the end of the day, when the wind blows side-offshore (fig. 4). This temperature increase is due to the provenance of the wind. In the morning and early afternoon, wind brings cool air from the sea and in the late afternoon warm air from inland.

There are a few cases showing characteristics of both groups B1 and B3, with stronger NW wind between 13 and $15 \mathrm{~h}$, as well as N or NNE at the end of the day.

Group B4 is special. In fact, moderate wind is constant, showing little turbulence. Wind blows from NW around 20 knots, but often only on the southern part of the beach during the whole afternoon, without presenting any change in direction. These cases are characterised by a cloud band located North of the Serra, which extends over the ocean (fig. 6a). The north part of the beach shows a well-defined calm area. 
Table IV - Some characteristics of the wind group days with a weak GFS wind forecast (group B). Quadro IV-Algumas características de grupos de dias com previsão (GFS) de vento fraco.

\begin{tabular}{|c|c|c|c|c|c|c|}
\hline Group & $\begin{array}{l}\text { OBSERVED wind } \\
\text { in Guincho }\end{array}$ & $\begin{array}{l}\text { PREDICTED } \\
\text { wind for Guincho } \\
\text { (GFS forecast) }\end{array}$ & Synoptic situation & $\begin{array}{l}\text { Temperatures } \\
\text { at Cabo Raso }\end{array}$ & Cloud occurrence & $\begin{array}{l}\text { OBSERVED wind } \\
\text { in Ericeira }\end{array}$ \\
\hline B1 & $\begin{array}{l}\text { Moderate NW wind, } \\
20-25 \text { knots, between } \\
12 \text { and } 15 \mathrm{~h}\end{array}$ & $\begin{array}{l}\text { - Morning: N or NE, } \\
\text { between } 5 \text { and } \\
10 \text { knots } \\
\text { - Afternoon: NW, } \\
\text { NNW and N, } \\
\text { 8-12 knots }\end{array}$ & $\begin{array}{l}\text { - Weak pressure gradient } \\
\text { - Atmospheric pressure } \\
\text { between } \\
1010-1020 \mathrm{hPa} \\
\text { - Anticyclone located } \\
\text { northwestwards from } \\
\text { Portugal }\end{array}$ & $\begin{array}{l}\text { - High daily } \\
\text { temperature } \\
\text { amplitude } \\
\text { (circa } 10{ }^{\circ} \mathrm{C} \text { ) } \\
\text { - Maximum } \\
\text { temperatures below } \\
30^{\circ} \mathrm{C}\end{array}$ & $\begin{array}{l}\text { - Possibly a cloud } \\
\text { band over the sea } \\
\text { (fig 6a) } \\
\text { or } \\
\text { - Clear sky. }\end{array}$ & \\
\hline B2 & $\begin{array}{l}\text { Moderate NW wind } \\
\text { in the afternoon } \\
-15-20 \text { knots) } \\
\text { between } 14 \mathrm{~h} \text { and } \\
17 \mathrm{~h}\end{array}$ & $\begin{array}{l}\text { - Morning: weak, less } \\
\text { than } 5 \text { knots } \\
\text {-Afternoon: NW, } \\
\text { NNW and N, } \\
\text { 6-12 knots }\end{array}$ & $\begin{array}{l}\text { - Portugal is located in a } \\
\text { barometric swamp } \\
\text { - Atmospheric pressure } \\
\text { between } 1012 \text { and } \\
1018 \mathrm{hPa} \\
\text { - Pressure decreases in } \\
\text { the afternoon }\end{array}$ & $\begin{array}{l}\text { - Moderate to high } \\
\text { daily temperature } \\
\text { amplitude } \\
\text { - Maximum temp. } \\
\text { below } 30^{\circ} \mathrm{C}\end{array}$ & $\begin{array}{l}\text { - Possibly a cloud } \\
\text { band over the sea } \\
\text { (fig 6a) }\end{array}$ & Weak wind \\
\hline B3 & $\begin{array}{l}\text { - Weak offshore wind } \\
\text { in the morning } \\
\text { - Weak NW wind in } \\
\text { the afternoon } \\
\text { - Moderate N-NNE } \\
\text { wind by the end } \\
\text { of the day } \\
\text { (20-25 knots) }\end{array}$ & $\begin{array}{l}\text { - Morning: NE and E, } \\
\text { 5-10 knots } \\
\text { - Afternoon: NNW } \\
\text { and N, 8-10 knots }\end{array}$ & $\begin{array}{l}\text { - Anticyclone } \\
\text { northwards from } \\
\text { Portugal } \\
\text { - Thermal low l over } \\
\text { Portugal } \\
\text { - Weak pressure gradient }\end{array}$ & $\begin{array}{l}\text { - Moderate to high } \\
\text { daily temp. } \\
\text { amplitude }\end{array}$ & & Weak wind \\
\hline $\mathrm{B} 1+3$ & $\begin{array}{l}\text { - NNE wind in the } \\
\text { morning } \\
\text { - NW wind in the } \\
\text { afternoon ( } 15 \text { knots) } \\
\text { - Moderate NNE } \\
\text { wind by the end } \\
\text { of the day } \\
\text { (20-25 knots) }\end{array}$ & $\begin{array}{l}\text { - Morning: N, NE or } \\
\text { E, relatively weak } \\
\text { (5-10 knots) } \\
\text { - Afternoon: NNW or } \\
\text { N, 8-12 knots }\end{array}$ & $\begin{array}{l}\text { - Anticyclone } \\
\text { northwards from } \\
\text { Portugal } \\
\text { - Thermal low over } \\
\text { Portugal } \\
\text { - Weak pressure gradient } \\
\text { - Pressure decreases in } \\
\text { the afternoon }\end{array}$ & $\begin{array}{l}\text { - High daily temp. } \\
\text { amplitude } \\
\text { - Temperature } \\
\text { increase by the end } \\
\text { of the day }\end{array}$ & & \\
\hline B4 & $\begin{array}{l}\text { - Morning: weak } \\
\text { WNW wind. } \\
\text {-Afternoon: regular } \\
\text { NW wind } \\
20-25 \text { knots on the } \\
\text { southern part of the } \\
\text { beach } \\
\text { - "No wind bubble" } \\
\text { - No wind on the } \\
\text { northern part of the } \\
\text { beach } \\
\text { - No wind direction } \\
\text { change throughout } \\
\text { the afternoon } \\
\text { (always NW) }\end{array}$ & $\begin{array}{l}\text { - Morning: NW, } \\
\text { NNW or N, } \\
\text { 6-11 knots } \\
\text { - Afternoon: NW and } \\
\text { NNW 8-12 knots, } \\
\text { decreasing in the } \\
\text { evening } \\
\text { or } \\
\text { - 14-17 knots NNW } \\
\text { or N winds blowing } \\
\text { throughout the night }\end{array}$ & $\begin{array}{l}\text { - Anticyclone over the } \\
\text { central or western } \\
\text { Atlantic } \\
\text { - Thermal low over the } \\
\text { Iberian Peninsula } \\
\text { - Moderate pressure } \\
\text { gradient }\end{array}$ & $\begin{array}{l}\text { - Low daily temp. } \\
\text { amplitude } \\
\text { - Maximum temp. } \\
\text { below } 20^{\circ} \mathrm{C}\end{array}$ & $\begin{array}{l}\text { - Cloud band behind } \\
\text { the Serra, spreading } \\
\text { over the sea. } \\
\text { (fig 6a) } \\
\text { - Altocumulus and } \\
\text { cirrocumulus } \\
\text { stratiformis in the } \\
\text { sky }\end{array}$ & Weak wind \\
\hline
\end{tabular}




\section{RESULTS APPLIED TO NAUTICAL SPORTS}

Ideal wind and weather conditions for water sports vary depending on the sport, the type of board, and the way the activity is pursued.

Windsurf wave riding requires an average minimum speed of 15 knots to be practised. Optimal conditions correspond to wind blowing side onshore (for jumping), side-shore or side offshore (for wave riding). The name of the discipline implies that waves are a necessary element. The larger and the more powerful the waves, the more skilled the windsurfer needs to be. Therefore, in Guincho, NW to NE wind direction is optimal to practice windsurfing and gusts may go up to 45-50 knots.

Kitesurfing requires a minimum wind speed of around 10 to 12 knots. Under optimal conditions, the wind has to blow side-shore, or onshore, which corresponds to W, WNW, NW, NNW and N in Guincho. An offshore wind is not favourable for kitesurfing. In Guincho, NNE-NE winds also allow the practice of kitesurfing, although there is a risk of kites falling into the water and drag the kitesurfer away from the shore. With winds above 30 knots, kitesurfing is considerably more dangerous, and when wind gusts exceed 40 knots, kitesurfing becomes extremely dangerous.

For surfing and bodyboarding, relatively weak wind blowing offshore is preferable. In fact, a wind coming from the sea "undoes" the waves. However, the wind is not the key factor for the surfer, although it does influence the quality of the waves.

This analysis has allowed to conclude that Guincho can offer good wind conditions for nautical sports, such as windsurfing, kite surfing and surfing, as presented in table $\mathrm{V}$.

For a windsurfer looking for strong winds, groups A1, A2, A3 and A4 are favourable, offering strong wind between 25 and 50 knots. In cases of groups A3 and A4, the possibility of exploring other beaches exists, such as Ericeira (fig.1), which offers more constant wind conditions. Groups A5 and A6 are not propitious to windsurfing, although the weather forecast seems good. Within groups B1, B2 and B3, the wind blows between 15 and 25 knots for only 2 or 3 hours, as referred above: on those days, it is important to reach the beach at the right time for practising windsurfing.

For kitesurfing, the situation is slightly different. Groups A1 and A2 can be adequate for kitesurfing on days when wind and wind gusts are not too violent and only reach 35 knots. Wind speeds above this level make it too dangerous for kitesurfing. Group A3 can offer great conditions during the day, before the wind increases considerably at the end of the day. Group A4 is not favourable for kitesurfing, as the strong gusts followed by windless moments may cause the kite to fall. In contrast to windsurfing, groups A5 and A6 are propitious for kitesurfing. In fact, wind blowing between 12 and 18 knots is not enough for practising windsurfing, but establishes great conditions for kitesurfing. Groups B1, B2 and B4, characterised by moderate onshore wind, are propitious to kitesurfing. Group B3 can offer more dangerous conditions for kitesurfing, due to side offshore wind.

Finally, most of the cases not considered in this analysis, representing days of light wind, are unsuitable for surfing and bodyboarding. Groups A2, A3 and A4 are clearly not adequate for these activities. However, for some cases in group A1, the wind may be light enough for practicing surf in the morning, as for groups B1, B2 and B3. Groups A5 and A6 are not adequate, due to the onshore wind. 
Table V - Wind groups in Guincho applied to different water sports.

Quadro V-Grupos de vento no Guincho adequadas a diferentes desportos náuticos.

\begin{tabular}{|c|c|c|c|c|}
\hline Group / activity & Wind conditions & Windsurfing & Kitesurfing & Surfing and bodyboarding \\
\hline A1 & $\begin{array}{l}\text { Strong NNW wind in the afternoon } \\
(20-50 \text { knots })\end{array}$ & $\begin{array}{l}\text { Good conditions in the } \\
\text { afternoon for strong wind adepts }\end{array}$ & $\begin{array}{l}\text { Good conditions in the } \\
\text { early afternoon }\end{array}$ & $\begin{array}{l}\text { In some cases, during the } \\
\text { morning }\end{array}$ \\
\hline A2 & $\begin{array}{l}\text { Strong NNW wind whole day long } \\
(20-50 \text { knots })\end{array}$ & $\begin{array}{l}\text { Good conditions for strong } \\
\text { wind adepts }\end{array}$ & Dangerous & Not adequate \\
\hline $\mathbf{A 3}$ & $\begin{array}{l}\text { Strong NNW or } N \text { wind by the end of the } \\
\text { day ( } 20-50 \text { knots) }\end{array}$ & $\begin{array}{l}\text { Good conditions by the end of } \\
\text { the day for strong wind adepts }\end{array}$ & $\begin{array}{l}\text { Reasonable conditions } \\
\text { during the day }\end{array}$ & Not adequate \\
\hline A4 & Very irregular NNW wind (0-40 knots) & Reasonable conditions. Gusty. & Dangerous & Not adequate \\
\hline A5 & $\begin{array}{l}\text { WNW-NW wind }-10 \text { to } 15 \text { knots, with gusts } \\
\text { reaching 20-25 knots }\end{array}$ & Relatively weak conditions & Good conditions & Not adequate \\
\hline A6 & $\begin{array}{l}\text { - NW-NNW, } \\
\text { - Very irregular wind 0-20 knots, } \\
\text { - "No wind bubble" }\end{array}$ & Bad conditions & Reasonable conditions & Not adequate \\
\hline B1 & $\begin{array}{l}\text { Moderate NW wind, reaching } 20-25 \text { knots, } \\
\text { between } 12 \text { and } 15 \text { h approximately }\end{array}$ & $\begin{array}{l}\text { Good conditions between } 13 \mathrm{~h} \\
\text { and } 15 \mathrm{~h}\end{array}$ & $\begin{array}{l}\text { Good conditions between } \\
13 \mathrm{~h} \text { and } 15 \mathrm{~h}\end{array}$ & $\begin{array}{l}\text { Good conditions in the } \\
\text { morning and at night } \\
\text { Not adequate between } 13 \mathrm{~h} \\
\text { and } 15 \mathrm{~h}\end{array}$ \\
\hline B2 & $\begin{array}{l}\text { Moderate NW wind in the afternoon } \\
(15-20 \text { knots) between } 14 \mathrm{~h} \text { and } 17 \mathrm{~h}\end{array}$ & $\begin{array}{l}\text { Reasonable conditions in the } \\
\text { afternoon }\end{array}$ & $\begin{array}{l}\text { Good conditions in the } \\
\text { afternoon }\end{array}$ & $\begin{array}{l}\text { Good conditions in the } \\
\text { morning }\end{array}$ \\
\hline B3 & $\begin{array}{l}\text { - Weak offshore wind in the morning } \\
\text { - Weak NW wind in the afternoon } \\
\text { - Moderate N-NNE wind by the end of the } \\
\text { day ( } 20-25 \text { knots })\end{array}$ & $\begin{array}{l}\text { Good conditions at the end of } \\
\text { the day }\end{array}$ & $\begin{array}{l}\text { Good conditions at the } \\
\text { end of the day }\end{array}$ & $\begin{array}{l}\text { Good conditions in the } \\
\text { morning }\end{array}$ \\
\hline B4 & $\begin{array}{l}\text { - Morning: weak WNW wind. } \\
\text { - Afternoon: regular NW wind 20-25 knots } \\
\text { on the southern part of the beach } \\
\text { - "No wind bubble" on the northern part } \\
\text { of the beach } \\
\text { - No wind direction change throughout the } \\
\text { afternoon (always NW) }\end{array}$ & $\begin{array}{l}\text { Good conditions in the } \\
\text { afternoon, on the southern part } \\
\text { of the beach }\end{array}$ & $\begin{array}{l}\text { Good conditions in the } \\
\text { afternoon, on the southern } \\
\text { part of the beach }\end{array}$ & $\begin{array}{l}\text { Reasonable conditions in the } \\
\text { morning }\end{array}$ \\
\hline
\end{tabular}

\section{CONCLUSION}

Guincho beach is characterised by very specific local weather phenomena. It is very popular for beach and bathing recreation, but at the same time it is a reference spot for several nautical activities, such as windsurfing, surfing and kitesurfing. For these activities, wind acts as a most significant climatic resource. The analysis carried out in this research work was essentially based on observation and prediction of surface wind data. It led to a useful classification enabling interpretation of the GFS surface wind forecasts used by most sportspeople in Guincho. 
The local wind phenomena, like many other local weather studies, are linked to different scale-effects. In some cases, wind blows due to the strong pressure gradient between the anticyclone and a thermal depression over Iberia (essentially group $\mathrm{A} 1$ and $\mathrm{A} 2$ ); in other cases, wind is due to, or intensified by, a local sea breeze (B1, B2 and B3). Local sea breeze is detected essentially with offshore gradient wind with less than 15 knots. In some cases, both phenomena succeed each other along the day.

The analysis led to the conclusion that global weather models do not accurately forecast the wind in Guincho, due to a lack of resolution or deficiencies in model parameterisations, which is due to the fact that local phenomena are poorly detailed by the weather model. Since Guincho is one of the very few locations on the European continent offering excellent conditions for water sports, such as windsurfing and kitesurfing, it will be necessary to improve forecasts, making available better weather forecasts with a higher resolution. Some private weather models (e.g. Predictwind, $1 \mathrm{~km}$ resolution) constitute an effective tool for these purposes, but may still be improved. A better knowledge of the wind would be a trump card for the organization of international sport events.

It would also be essential to predict the "no-wind bubble". This term means an area without wind in the wave zone, when wind blows moderate offshore. This complex phenomenon can have several origins, such as wind eddies generated on the slopes of the relief. The centre of these eddies corresponds to areas without wind. In these cases, wind is variable, with wind direction shifts reaching $180^{\circ}$. This phenomenon also occurs when overheated areas on the beach or on the slopes of the Serra generate warm air bubbles that "push" wind upwards. In order to develop this study, it is important to deal with some important meteorological topics of the atmospheric boundary layer: (i) study the stability in low layers of the atmosphere, through vertical surveys; or (ii) apply standard classifications such as the Froude number. But in order to deepen this study, an analysis of air temperature data from stations located on land as well as at sea is required.

The follow-up of this research within an ongoing $\mathrm{PhD}$ thesis will not focus exclusively on the Guincho area. It will also include analysis of the behaviour of summer wind (including the Nortada) at different scales and in other points of the Portuguese western coast, where nautical sports are carried out (such as Peniche, Ericeira and Costa da Caparica).

\section{ACKNOWLEDGEMENTS}

This paper draws on a Master's thesis by Wenzel Vermeersch, presented to IGOT-UL. The research is part of the project "Wind Power Assessment, Urban Environment and Tourism in Cascais", financed by the Municipality of Cascais. The authors are grateful to the anonymous reviewers for providing valuable comments that helped improve the manuscript. They also warmly thank Madalena Cruz-Ferreira for proofreading the English versions of this paper. 


\section{BIBLIOGRAPHY}

Alcoforado MJ, Nunes MF, Garcia JC, Taborda JP (2000) Temperature and precipitation reconstruction in southern Portugal during the Late Maunder Minimum (AD 1675-1715). The Holocene, 10(3): 333-340.

Alcoforado MJ, Andrade H, Lopes A, Vasconcelos J, Vieira R (2006) Observational studies on summer winds in Lisbon (Portugal) and their influence on daytime regional and urban thermal patterns. Merhavim, 6: 90-112.

Alcoforado MJ (1984). Os ventos dominantes em torno da Serra de Sintra. A deformação das árvores. Finisterra - Revista Portuguesa de Geografia, 19(38): 137-169.

Bernot J-Y (2007) Météo locale croisière et régate. Fédération Française de Voile/Gallimard, Paris.

Grupo de trabalho da náutica de recreio Maroceano (2012) Náutica de recreio em Portugal, um pilar do desenvolvimento local e da economia do mar. Óbidos, Sinapis editores.

Instituto Hidrográfico (2004) Roteiro da Costa de Portugal - Do Cabo Carvoeiro ao Cabo de São Vicente. Instituto Hidrográfico, Lisboa.
Jennings G (2009) Water-Based Tourism, Sport, Leisure, and recreation experiences. Butterworth-Heinemann, Oxford.

Mayençon R (1982) Metéorologie marine. Editions Maritimes et d'Outre-Mer, France.

Miranda P M A (2001) Meteorologia e ambiente. Universidade Aberta, Lisboa.

Neves M (2004) Evolução actual dos litorais rochosos da Estremadura Norte. Estudo de Geomorfologia, PhD Thesis, Institute of Geography and Spatial Planning (IGOT), University of Lisbon (in Portuguese, with an English summary).

Simpson J (1994) Seabreeze and local winds. Cambridge University Press.

Vermeersch W (2011) The wind conditions in Guincho: a climate study applied to nautical sports. Master Thesis, Institute of Geography and Spatial Planning (IGOT), University of Lisbon, 2011 (in Portuguese, with an English summary).

Watts A (1973) Wind and sailing boats. David \& Charles, Newton Abbot.

i The wind speed in this work is expressed in knots, that correspond to one nautical mile per hour $(1 \mathrm{knot}=1,852 \mathrm{~km} / \mathrm{h}=0,514 \mathrm{~m} / \mathrm{s})$. "Knots" is the main unit used for maritime activities and watersports, and it appeared to us to be the most adequate unit to deal with this topic. 